\title{
Toxic Granulation Measurement
}

National Cancer Institute

\section{Source}

National Cancer Institute. Toxic Granulation Measurement. NCI Thesaurus. Code C96641.

The determination of the toxic granulation in neutrophilic blood cells. 